Journal Homepage:

http://perlinguam.journals.ac.za

\section{Per Linguam}

A Journal for Language Learning Tydskrif vir Taalaanleer

\title{
Preface to Per Linguam
}

Given that reading comprehension is at the forefront of global literacy discourse, this special edition of Per Linguam, the first number that is also published online, features a collection of articles that cover different aspects of reading comprehension and instruction, such as, strategies for comprehending texts, metacognitive awareness, the reciprocity of assessment and comprehension instruction and socio-affective factors that influence comprehension.

The first two articles focus on reading comprehension instruction for intermediate and senior phase learners. Lepalala and Pretorius describe the effect a reading comprehension programme had on Grade 6 learners' reading performance in Northern Sotho and in English. The results of their study suggest that a decoding intervention that runs concurrently with a comprehension intervention would serve the weaker readers better than interventions that focus only on improving comprehension. They concede that there is a multiplicity of factors that contribute to the successful implementation of a comprehension programme. More specifically, they recommend that future interventions should find ways of assessing key elements of comprehension, such as metacognitive awareness, more directly. Klapwjik and Van der Walt's article connects with this latter point. Their study demonstrates that strategy instruction can help grade 5 learners develop a meta-knowledge of reading strategies, which suggests that they will be able to implement reading strategies to comprehend texts. Furthermore, their article provides evidence that strategy knowledge transfer is measurable and can, therefore, be used as motivation for teachers to implement reading strategy instruction in a sustainable fashion.

The next two articles concentrate on the reciprocal roles assessment and instruction play in developing the comprehension abilities of foundation phase learners. Nel argues that beginner reader programmes and assessments tend to over-emphasise children's decoding skills and neglect their comprehension skills. She contends that the critical role assessment plays in comprehension instruction has been seriously underestimated by universities. Therefore, she highlights the importance of teaching pre-service, foundation phase teachers how to analyze and

use assessment data to develop individual learners' comprehension strategies. Swart and Nathanson's article contributes to this discussion by demonstrating that learner data obtained from systematic assessments can help low-performing readers progress from mere decoding to comprehending text. 
The last three articles foreground socio-affective factors that influence reading development, such as, learners' attitudes, motivation, interests and backgrounds. Linking up with the problems of second language learners developing reading proficiency in English, Nchindila offers suggestions to improve phonological awareness in such readers. Hibbert and Crous agree that children's affective engagement with reading is essential for developing a sense of agency and ensuring a lifelong love of reading. Their article outlines some universal characteristics of reading materials for beginner readers, as well as specific criteria for choosing materials for Southern African children. They contend that translated children's stories should ideally be adapted rather than literally translated, in order to meet the requirements of what is universally regarded as good children's literature for beginner readers. Boakye argues for the inclusion of socio-affective scaffolding in tertiary level reading development programmes and proposes a multifaceted model on which to map reading instruction at tertiary level that combines both affective and cognitive factors.

We hope that the perspectives raised in these articles will stimulate further research that can increase reading teachers' understanding of how to teach comprehension at all education levels.

Renée Nathanson (Guest Editor)

rrn@sun.ac.za 